\title{
Effects of plant growth regulators and explant type on the in vitro micro-propagation of wild ginger (Siphonochilus aethiopicus (Schweif.) B.L. Burt.)
}

\author{
E. N. Kunene ${ }^{1 *}$, T. O. Oseni ${ }^{2}$, P. K. Wahome ${ }^{2}$, M. T. Masarirambi ${ }^{2}$, M. J. McCubbin ${ }^{3}$, P. S. \\ Dlamini $^{1}$, S. A. Sihlongonyane ${ }^{2}$ and M. G. Zwane ${ }^{2}$ \\ ${ }^{1}$ Eswatini Institute for Research in Traditional Medicine, Medicinal and Indigenous Food Plants (EIRMIP), University of \\ Eswatini, Private Bag 4 Kwaluseni M201, Eswatini. \\ ${ }^{2}$ Department of Horticulture, University of Eswatini, P.O. Luyengo, Luyengo M205, Eswatini. \\ ${ }^{3}$ Pasture Valley (Pty) Ltd., P.O. Box 1129 Nhlangano S400, Eswatini.
}

Accepted 5 October, 2018

\begin{abstract}
Wild ginger is a medicinal plant which belongs to Zingeberaceae family. It is used in traditional medicine for the treatment of coughs, colds, flu, malaria and menstrual disorders. However, the plant is at the verge of extinction due to unsustainable harvesting practices. The objective of this study was to develop in vitro micro-propagation protocol for the wild ginger. The MS media with 0.0, 0.5, 1.0, $2.0 \mathrm{mg} \mathrm{L}^{-1} \mathrm{BAP}, 2.0 \mathrm{mg} \mathrm{L}^{-1}$ $\mathrm{BAP}+0.5 \mathrm{mg} \mathrm{L}^{-1} \mathrm{NAA}$, and $2.0 \mathrm{mg} \mathrm{L}^{-1} \mathrm{BAP}+1.0 \mathrm{mg} \mathrm{L}^{-1} \mathrm{NAA}$, were evaluated on leaf, corm and root explants for in vitro shoot regeneration via direct organogenesis. In vitro rooting was investigated on half strength MS medium augmented with $0.0,0.5,1.0,1.5$ and $2.0 \mathrm{mg} \mathrm{L}^{-1}$ NAA. Corm explants were significantly more effective in direct shoot regeneration in vitro than the leaf and root explants which neither regenerated shoots nor formed callus. The $1.0 \mathrm{mg} \mathrm{L}^{-1}$ BAP produced shoots which were significantly higher in number and longer than those from other treatments. However, there was no significant difference between 1.0 and $0.5 \mathrm{mg} \mathrm{L}^{-1}$ BAP. There was also no significant difference between the PGR-free MS medium and $0.5 \mathrm{mg} \mathrm{L}^{-1}$ BAP. No shoots were observed on $2.0 \mathrm{mg} \mathrm{L}^{-1} \mathrm{BAP}$, and on either of the combination of BAP and NAA. The half strength MS medium was effective on in vitro rooting, with no significant differences among the NAA concentrations on rooting percentage, number of roots and root length. From the results of this trial, it can be recommended that corm explants be used for direct shoot regeneration of wild ginger in vitro, with BAP of up to $1.0 \mathrm{mg} \mathrm{L}^{-1}$, and be rooted on half strength MS medium supplemented with NAA of up to $2.0 \mathrm{mg} \mathrm{L}^{-1}$.
\end{abstract}

Keywords: Wild ginger, medicinal plant, BAP, NAA, shoot regeneration, direct organogenesis, biodiversity.

*Corresponding author. E-mail: enkunene@uniswa.sz.

\section{INTRODUCTION}

Wild ginger, also called African ginger, (Siphonochilus aethiopicus (Schweif.) B.L. Burt.), belongs to Zingeberaceae family. This family is well known for its spice plants, including real ginger (Zingiber officinale), cardamom (Elletaria cardamomum), turmeric (Curcuma longa) and exotic garden ginger (Hedychium) (Light, 2002). The fresh rhizomes and roots are very popular in traditional medicine in southern Africa (Fouche et al., 2013). The main traditional use of wild ginger is for the treatment of coughs, colds, flu, malaria and menstrual disorders (Manzini, 2005). The wild ginger represents a valuable indigenous resource which has potential for future profit in small-scale agriculture for use in traditional medicine and in the more sophisticated pharmaceutical industry (Light, 2002). The plant kingdom provides a nonexhaustive source of natural phytochemicals with bioactivity efficient in different applications for treating health disorders and maintenance of good health (Ahmed 
et al., 2014). Herbal medicine usage is one of the most remarkable uses of plant based biodiversity (Xego et al., 2016).

However, most of the medicinal plant species used in traditional medicine are threatened with extinction, as they are not being harvested in a sustainable manner and because of great pressure for industrial activities, commercial agricultural activities and human settlement (Tasheva and Kusturkova, 2013). Indiscriminate harvesting of medicinal plants can be problematic in terms of biodiversity loss, potential variation in medicinal plant quality, and occasionally, improper plant identification with potential tragic consequences (Briskin, 2000).

Plant materials procured from naturally occurring stands are being rapidly depleted because of the use of parts like roots, bark, wood, stem and the whole plant in the case of herbs (Malik et al., 2012). The wild ginger is not an exception since the whole plant is harvested for its corms, rhizomes and roots, which are used for traditional herbal medicine in Eswatini. The wild ginger is now highly endangered and almost extinct in some areas. In actual fact, the wild ginger is listed under the red tape in the Plant Protection Act of the Kingdom of Eswatini (Swaziland National Trust Commission, 2016). This poses a specific threat to the genetic stocks and to the diversity of medicinal plants (Malik et al., 2012).

Public cultivation information on the wild ginger is hardly available (Hartzell, 2011). There has not been any attempt to domesticate and propagate this valuable medicinal plant which is critically endangered in Eswatini, and has already been declared as a red tape plant species. Kunene and Masarirambi (2018) expressed the need to develop micropropagation protocols for all the plant species threatened with extinction in Eswatini. The objective of this research work was to develop micropropagation protocol of wild ginger using plant tissue culture technology.

\section{MATERIALS AND METHODS}

\section{Experimental site}

The trials were conducted in a private commercial Tissue Culture Laboratory at Pasture Valley Farm. The farm is located at $27^{\circ} 05^{\prime} 17.8^{\prime \prime}$ South and 031 $10^{\prime} 29.9^{\prime \prime}$ East, about six kilometres away from Nhlangano town, in the Shiselweni region of the Kingdom of Eswatini.

\section{Plant materials}

The wild ginger plant materials were collected from Ekwakheni community, around Maguga dam area, in the Hhohho region of the Kingdom of Eswatini. The area is located at $26^{\circ} 04^{\prime} 41.4^{\prime \prime}$ South and $031^{\circ} 16^{\prime} 30.2^{\prime \prime}$ East. The average altitude of this location is $563.3 \mathrm{~m}$ a.s.l. The plants were then grown, using their rhizomes, corms and roots, in commercial compost in the plant nursery at Pasture Valley farm. The nursery grown plants were then used as source of explants for the in vitro micro-propagation of wild ginger

\section{Preparation of plant materials}

The plants were harvested when they were at the seedling stage, one to two weeks post emergence. The harvested plants were thoroughly washed in running tap water for 45 minutes. Leaves, corms and roots were used as explants in this trial. Explants were cut, using scalpel and knife, to about $1.0-1.5 \mathrm{~cm}$ long. They were then rinsed again in tap water. Surface sterilisation was performed by immersion of the explants in $3.5 \%(\mathrm{~m} / \mathrm{v})$ sodium hypochlorite solution (1:1) with two drops of Tween $20 / 100 \mathrm{ml}$ for 15 minutes while shaking. This was followed by four rinses in sterile deionized water. Surface sterilization and rinsing were done in the laminar airflow cabinet (manufactured by Airvolution Lab, Mogale City, South Africa).

\section{Culture media preparation}

The Murashige and Skoog (1962) basal medium (MS medium) was used in this experiment. Plant growth regulators were added according to experimental objectives. Sucrose, $30 \mathrm{~g} \mathrm{~L}^{-1}$, was added and stirred with a magnetic stirrer to dissolve. The $\mathrm{pH}$ was adjusted to $5.8 \pm 0.1$ using Sodium Hydroxide $(\mathrm{NaOH})$ and $0.1 \mathrm{M}$ Hydrochloric acid $(\mathrm{HCl})$. The media were gelled by application of 8 $\mathrm{g} \mathrm{L}^{-1}$ agar-agar. The media were heated for four minutes in a microwave oven to melt the agar before dispensing into culture vials. Approximately $20 \mathrm{ml}$ of medium was dispensed in $60 \mathrm{ml}$ vials.

Autoclaving (Autoclave manufactured by Gemmy Industrial Corp., Taipei, China) was done for $20 \mathrm{~min}$ at $121^{\circ} \mathrm{C}$ and 1.06 $\mathrm{kg} / \mathrm{cm}^{2}$ pressure (Dharishini et al., 2015). Deionised water, forceps, scalpels, blotting paper, beakers, volumetric flasks, and cloth wiper, which were materials used for the aseptic manipulation of explants, were autoclaved under similar conditions. The cultures were grown at $25^{\circ} \mathrm{C}$ under 16 hours of light, using cool white fluorescent lamps, and eight hours of darkness.

\section{Experimental layout}

The trial was laid out in a randomised complete block design (RCBD). One explant was cultured in each vial, where four vials represented an experimental unit. There were six replications of each treatment for the establishment cycle. The experiment was repeated three times. There were three sub-cultures, and each subculture cycle was four weeks.

\section{Regeneration of plants by organogenesis}

The explants were inoculated onto MS medium with varying concentrations of 6-Benzylaminopurine (BAP) and 1-naphthalene acetic acid (NAA) for direct shoot regeneration. The treatments were as follows:
A. $\quad \mathrm{MS}+0.0 \mathrm{mg} \mathrm{L}^{-1} \mathrm{BAP}$
B. $\quad \mathrm{MS}+0.5 \mathrm{mg} \mathrm{L}^{-1} \mathrm{BAP}$
C. $\quad \mathrm{MS}+1.0 \mathrm{mg} \mathrm{L}^{-1} \mathrm{BAP}$
D. $\quad \mathrm{MS}+2.0 \mathrm{mg} \mathrm{L}^{-1} \mathrm{BAP}$
E. $\quad \mathrm{MS}+2.0 \mathrm{mg} \mathrm{L}^{-1} \mathrm{BAP}+0.5 \mathrm{mg} \mathrm{L}^{-1} \mathrm{NAA}$
F. $\quad \mathrm{MS}+2.0 \mathrm{mg} \mathrm{L}^{-1} \mathrm{BAP}+1.0 \mathrm{mg} \mathrm{L}^{-1} \mathrm{NAA}$

\section{Shoot multiplication}

The regenerated shoots were excised and sub-cultured into a new culture medium for multiplication. The MS medium augmented with $1.0 \mathrm{mg} \mathrm{L}^{-1}$ BAP was used for the multiplication phase. 


\section{Rooting of regenerated plantlets}

Shoots obtained by direct organogenesis and/or shoot proliferation were inoculated onto half strength MS medium containing different concentrations of NAA to induce roots. The media used were as follows:

$\begin{array}{ll}\text { G. } & 1 / 2 \mathrm{MS} \text { medium + } 0.0 \mathrm{mg} \mathrm{L}^{-1} \mathrm{NAA} \\ \text { H. } & 1 / 2 \mathrm{MS} \text { medium }+0.5 \mathrm{mg} \mathrm{L}^{-1} \mathrm{NAA} \\ \text { I. } & 1 / 2 \mathrm{MS} \text { medium + } 1.0 \mathrm{mg} \mathrm{L}^{-1} \mathrm{NAA} \\ \text { J. } & 1 / 2 \mathrm{MS} \text { medium }+1.5 \mathrm{mg} \mathrm{L}^{-1} \mathrm{NAA} \\ \text { K. } & 1 / 2 \mathrm{MS} \text { medium + } 2.0 \mathrm{mg} \mathrm{L}^{-1} \mathrm{NAA}\end{array}$

\section{Data collection and analysis}

Data were collected on the following parameters: number of explants which regenerated shoots (\%), number of regenerated shoots per explant, regenerated shoot length, rooting percentage, number of roots per plantlet, and root length $(\mathrm{cm})$.

Data were subjected to analysis of variance (ANOVA) through Statistical Package for Social Sciences version 20 (SPSS 20).
Where significant differences were detected, mean separation test was performed using the Duncan's New Multiple Range Test (DNMRT).

\section{RESULTS}

\section{Explant material}

After a period of 7 to 14 days, direct shoot regeneration without intermediate callus phase was observed on the corm explants (Figure 1).

There was significant $(P<0.05)$ difference between the explants (corms, leaves and roots) on direct shoot regeneration of wild ginger in vitro (Figure 2).

Corm explants were significantly more effective in direct shoot regeneration of the wild ginger in vitro compared to the leaf and roots explants which neither directly regenerated shoots nor formed callus by the end of the four-week establishment stage (Figure 3).

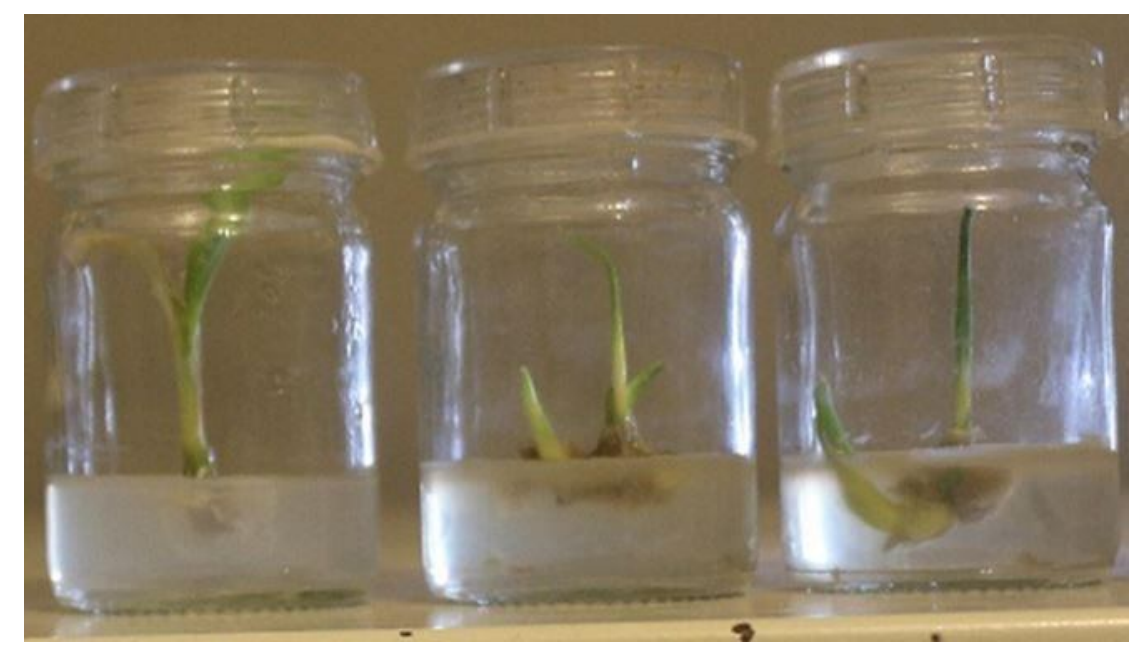

Figure 1. Direct shoot regeneration of wild ginger from corm explants during the establishment stage.

\section{Shoot regeneration}

Plant growth regulators significantly $(P<0.05)$ affected direct shoot regeneration of wild ginger in vitro (Figure 4). The MS media supplemented with low concentrations of BAP $\left(0.5 \mathrm{mg} \mathrm{L}^{-1}\right.$ and $\left.1.0 \mathrm{mg} \mathrm{L}^{-1}\right)$ induced significantly $(P<$ $0.05)$ higher number of shoots compared to the MS media augmented with high concentration of BAP (2.0 $\mathrm{mg} \mathrm{L}^{-1}$ ) and both the concentrations of the combination of BAP and NAA (Figure 4). However, there was no significant $(P>0.05)$ difference between the MS medium without any plant growth regulator (the control) and the MS medium supplemented with $0.5 \mathrm{mg} \mathrm{L}^{-1}$ BAP (Figure 4). Shoots regenerated even in the MS medium devoid of plant growth regulators. There was no significant $(P>$
0.05) difference between the MS medium augmented with $0.5 \mathrm{mg} \mathrm{L}^{-1}$ BAP and $1.0 \mathrm{mg} \mathrm{L}^{-1}$ BAP either (Figure 4).

Neither did BAP at $2.0 \mathrm{mg} \mathrm{L}^{-1}$ nor the combination concentrations of BAP and NAA $\left(2.0 \mathrm{mg} \mathrm{L}^{-1} \mathrm{BAP}+0.5\right.$ $\mathrm{mg} \mathrm{L}^{-1} \mathrm{NAA}$, and $\left.2.0 \mathrm{mg} \mathrm{L}^{-1} \mathrm{BAP}+1.0 \mathrm{mg} \mathrm{L}^{-1} \mathrm{NAA}\right)$ regenerate shoots in vitro. The MS medium augmented with $1.0 \mathrm{mg} \mathrm{L}^{-1}$ had significantly $(P<0.05)$ higher rate of direct shoot regeneration than the control MS medium and the MS media supplemented with the combination of BAP and NAA at both concentrations (Figure 4).

\section{Multiplication}

The micro-shoots which were regenerated from corm 


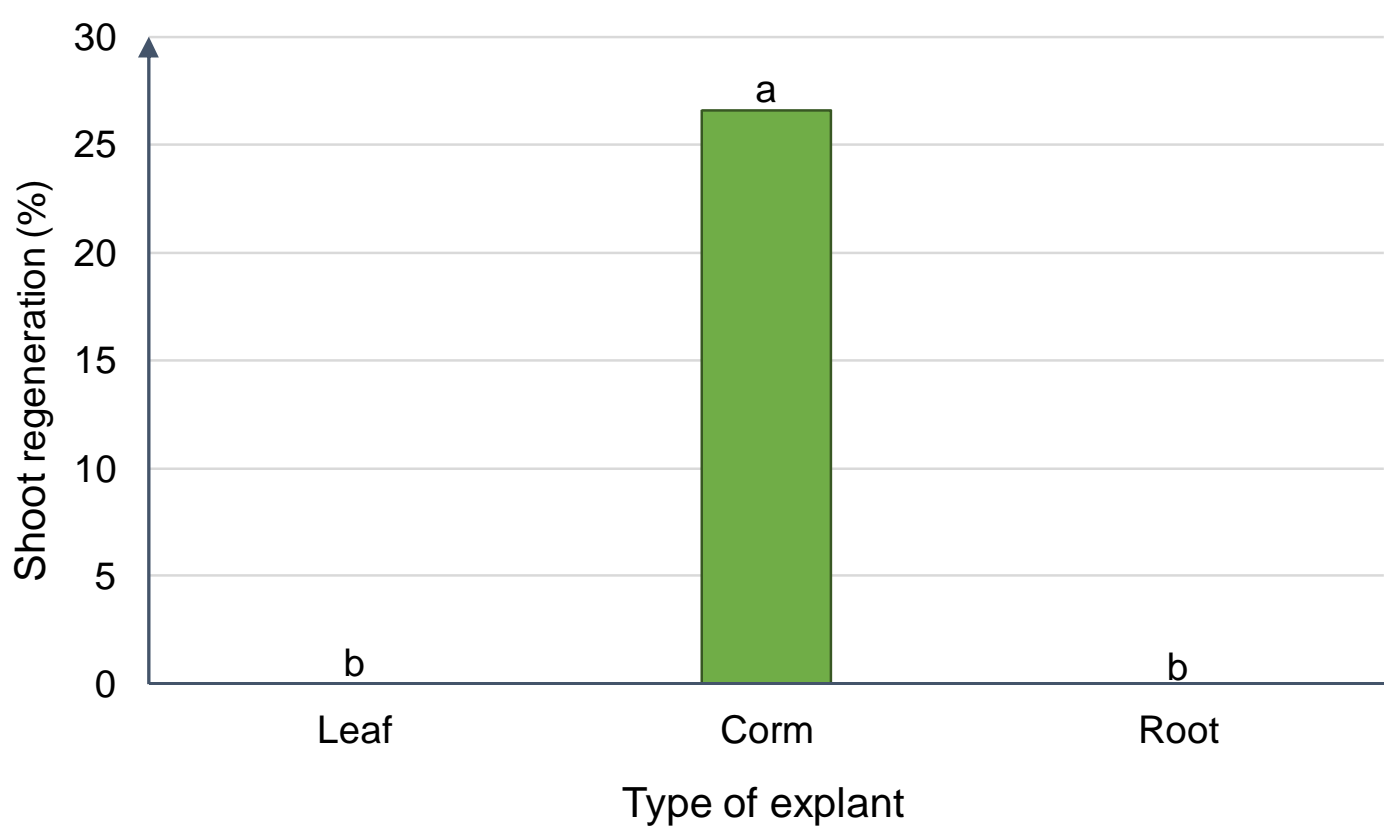

Figure 2. Response of the different types of explants of wild ginger to direct shoot regeneration in vitro. Bars followed by the same letter are not significantly different from each other according to DNMR test $(P=0.05)$.

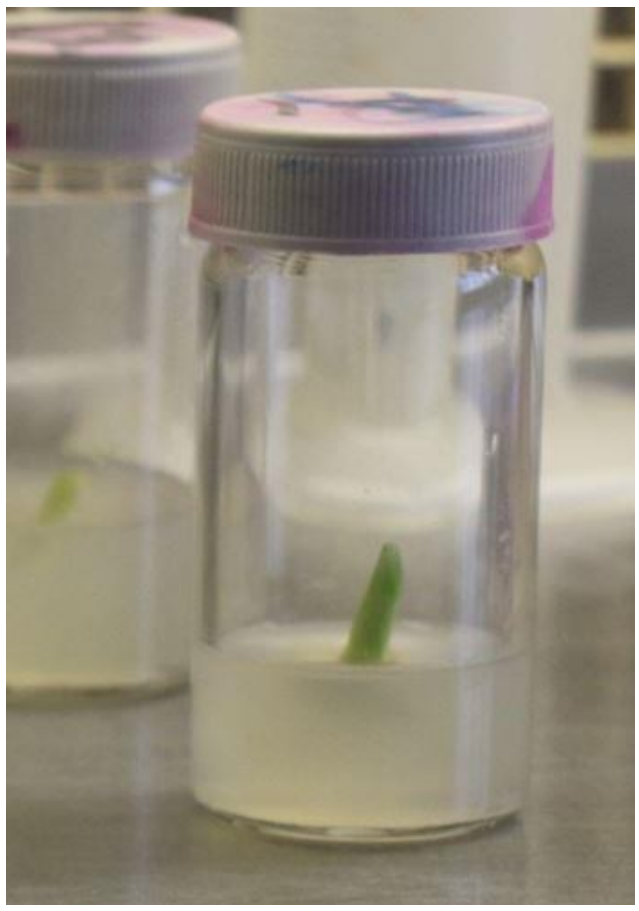

Figure 3. Leaf explant at four weeks during establishment in vitro.

explants through direct organogenesis were sub-cultured in MS medium supplemented with $1.0 \mathrm{mg} \mathrm{L}^{-1}$ BAP, for multiplication. Each micro-shoot produced an average of three shoots during the multiplication phase (Figure 5).

\section{Micro-shoot length}

The plant growth regulators significantly $(P<0.05)$ influenced the length of regenerated shoots in vitro. Shoots which regenerated on MS medium augmented with $1.0 \mathrm{mg} \mathrm{L}^{-1}$ BAP were significantly $(P<0.05)$ longer than those which regenerated on MS medium devoid of any plant growth regulators (Figure 6). However, there was no significant $(P>0.05)$ difference between the MS media augmented with $0.5 \mathrm{mg} \mathrm{L}^{-1}$ BAP and $1.0 \mathrm{mg} \mathrm{L}^{-1}$ BAP with respect to shoot length (Figure 6). Shoots which regenerated on MS medium devoid of any plant growth regulators were statistically the same length with those which regenerated on MS medium augmented with $0.5 \mathrm{mg} \mathrm{L}^{-1}$ (Figure 6). There were no regenerated shoots observed on MS medium supplemented with $2.0 \mathrm{mg} \mathrm{L}^{-1}$ BAP and on either of the combination concentrations of BAP and NAA (Figure 5).

\section{In vitro rooting of wild ginger}

The different NAA concentrations, including the control, did not differ significantly $(P>0.05)$ with regards to rooting percentage (Figure 7 ), number of roots per shoot (Figure 8) and root length (Figure 9) of wild ginger in vitro (Figure 10).

\section{DISCUSSION}

The concentration of BAP in the MS medium and the type 


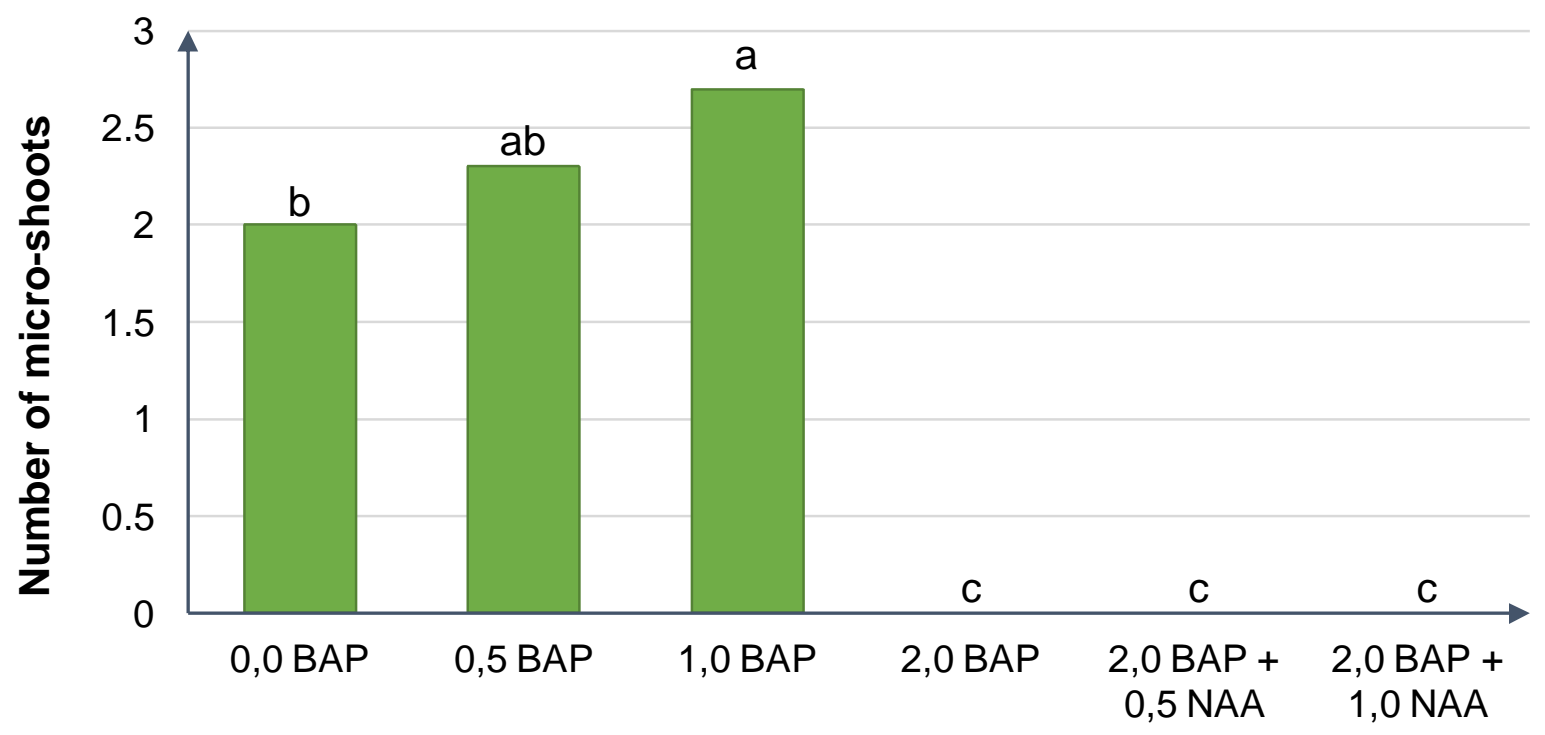

\section{Concentration of PGRs (mg L-1)}

Figure 4. Influence of plant growth regulators (PGRs) on the number of micro-shoots regenerated in vitro. Bars followed by the same letter are not significantly different from each other according to DNMR test $(P=0.05)$.

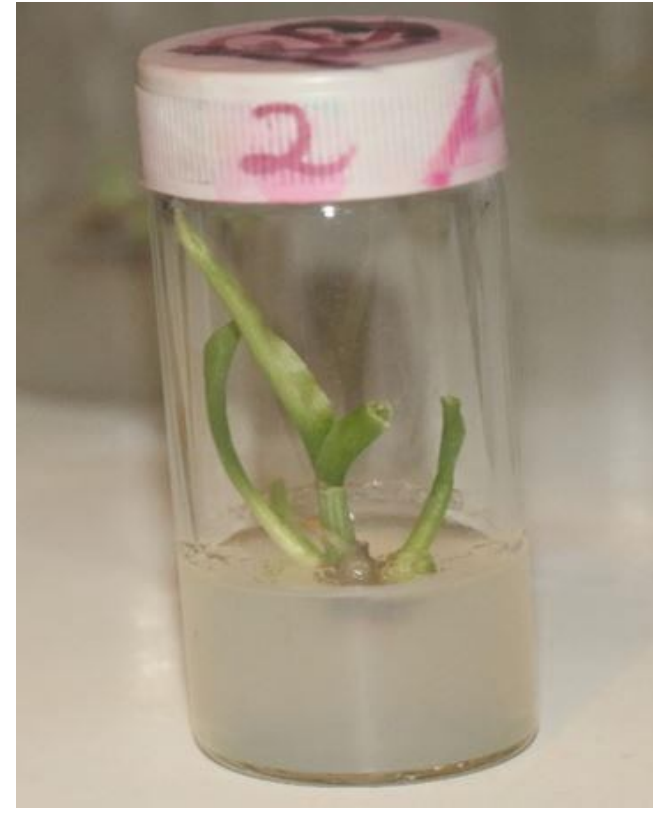

Figure 5. In vitro multiplication of wild ginger micro-shoots in MS + $1.0 \mathrm{mg} \mathrm{L}^{-1}$ BAP.

of explant significantly influenced the shoot regeneration response. Such a difference may be caused by different concentrations of endogenous plant growth regulators and metabolism rates (Mokhtari et al., 2016). On shoot regeneration of Spilanthes mauritiana, three explants viz. shoot tip, nodal segments and leaf explants were found that they significantly influenced direct shoot regeneration in vitro (Sharma et al., 2009). From the present investigation, shoots were regenerated directly from the corm explants, and no shoots were induced from leaf and root explants. The possible explanation for this could be that corms have meristematic nodes which make them effective to directly initiate shoots when cultured in best conditions (Cavusoglu et al., 2013). Axillary buds are produced at each of the nodes, and the bulk of the corm consists of storage tissue composed of parenchyma cells (Hartmann et al., 2002). The problem accompanying shoot regeneration from corms and rhizomes concerns scarcity of initial explants and their heavier contamination (Nasri et al., 2013). Generally, contamination of field grown rhizomes is the persistent problem under in vitro conditions since rhizomes contact with the soil (Seran, 2014). The size of the explant could be a determinant of endogenous contamination. Very small explants are less transmitting endogenous infestation (Seran, 2014). Low corm multiplication rates and fungal infestation of corms reduce their productivity and quality (Cavusoglu et al., 2013).

Leaf and root explants did not regenerate shoots in any of the media used in this trial. Contrary to the current study, shoot regeneration occurred only from the base of Lilium leaf explants, however, the apical part of leaf did not show any regeneration (Bacchetta et al., 2003). Abdi and Khosh-Khun (2007) also reported that leaf explants of Valerina officinalis exhibited shoot bud induction within 30 days. No callus formation was observed in any of the explants used in the present study. This observation is in agreement with Nasri et al. (2013) who reported that the shoots regeneration on Alstroemeria ligtu always 


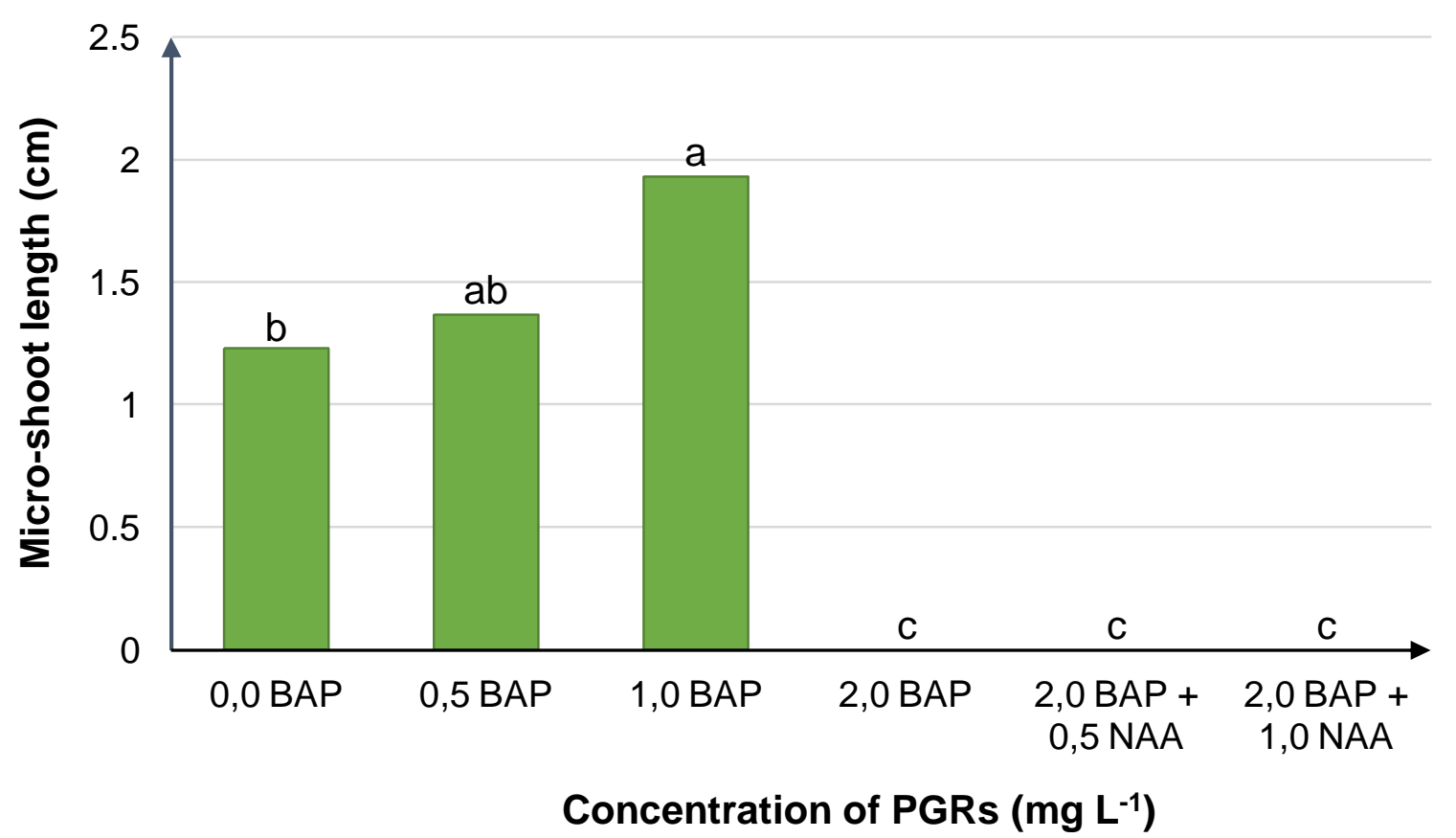

Figure 6. Influence of plant growth regulators (PGRs) on length of micro-shoot in vitro. Bars followed by the same letter are not significantly different from each other according to DNMR test $(P=0.05)$.

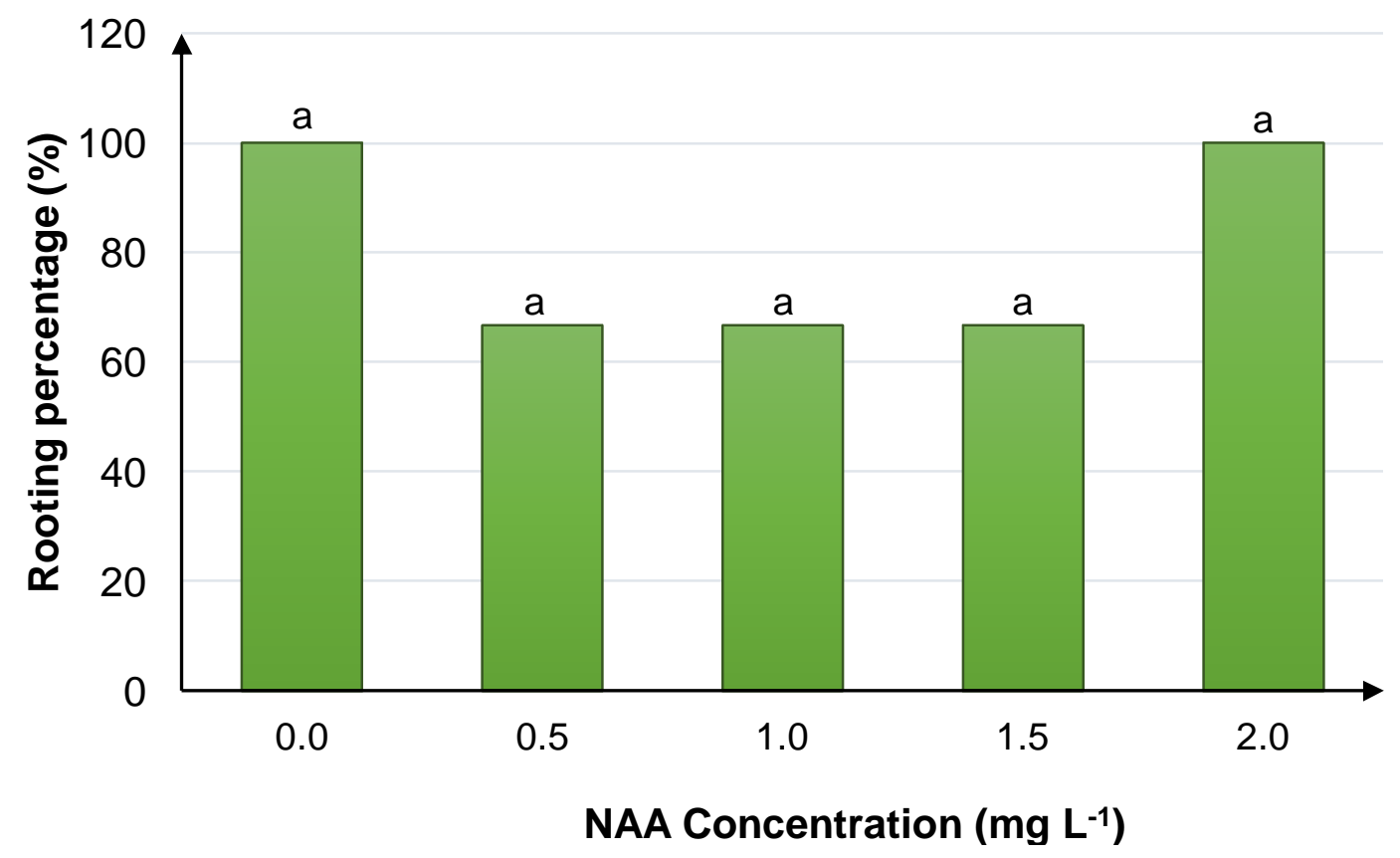

Figure 7. Effects of NAA concentrations on in vitro rooting of wild ginger. Bars followed by the same letter are not significantly different from each other according to DNMR test $(P=0.05)$.

occurred directly without forming callus. Shoots regenerated directly without callus phase pose lower risk of genetic variation (Nasri et al., 2013).

An increase in BAP concentration from 0.0 to $1.0 \mathrm{mg} \mathrm{L}^{-1}$ stimulated the increase of adventitious shoots number on
Alstroemeria ligtu (Nasri et al., 2013). Similarly, in the current study, an increase of BAP from 0.0 to $1.0 \mathrm{mg} \mathrm{L}^{-1}$ increased the number of shoots and shoot length on wild ginger. A pattern of significant increment in the regenerated microshoots was observed as the 


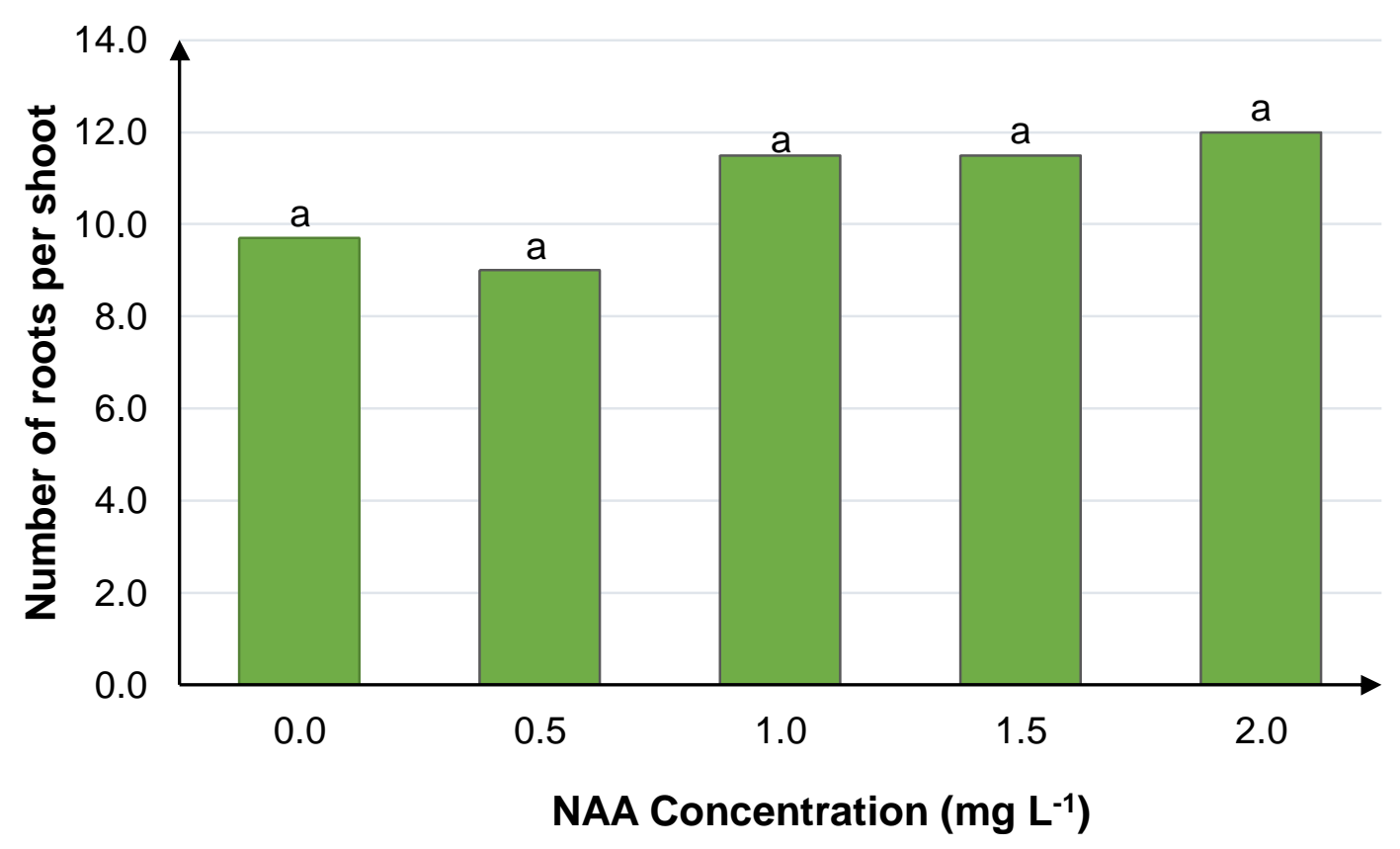

Figure 8. Effects of NAA concentrations on number of roots per shoot of wild ginger in vitro. Bars followed by the same letter are not significantly different from each other according to DNMR test $(P=$ 0.05).

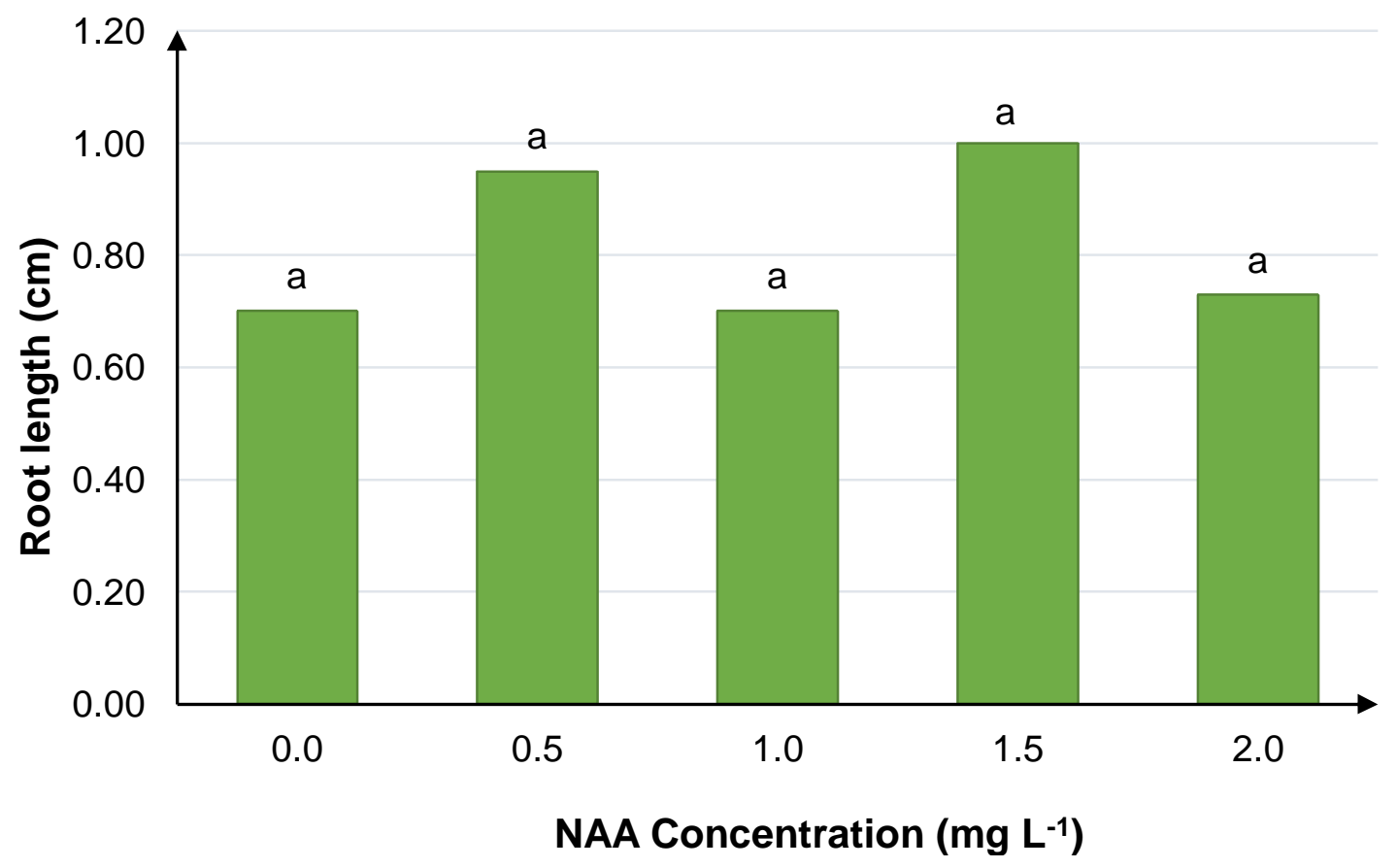

Figure 9. Effects of NAA concentrations on number of roots per shoot. Bars followed by the same letter are not significantly different from each other according to DNMR test $(P=0.05)$.

concentration of BAP increased compared to control. This proves that cytokinin influences the development of micro-shoots on the explants (Zuraida et al., 2016). Concentrations of BAP higher than $1.0 \mathrm{mg} \mathrm{L}^{-1}$ caused a reduction in shoot number of Alstroemeria ligtu (Nasri et al., 2013). In the current investigation, BAP at 0.5 and 1.0 $\mathrm{mg} \mathrm{L}^{-1}$ produced shoot number and shoot length which were statistically the same. Similar results were reported 


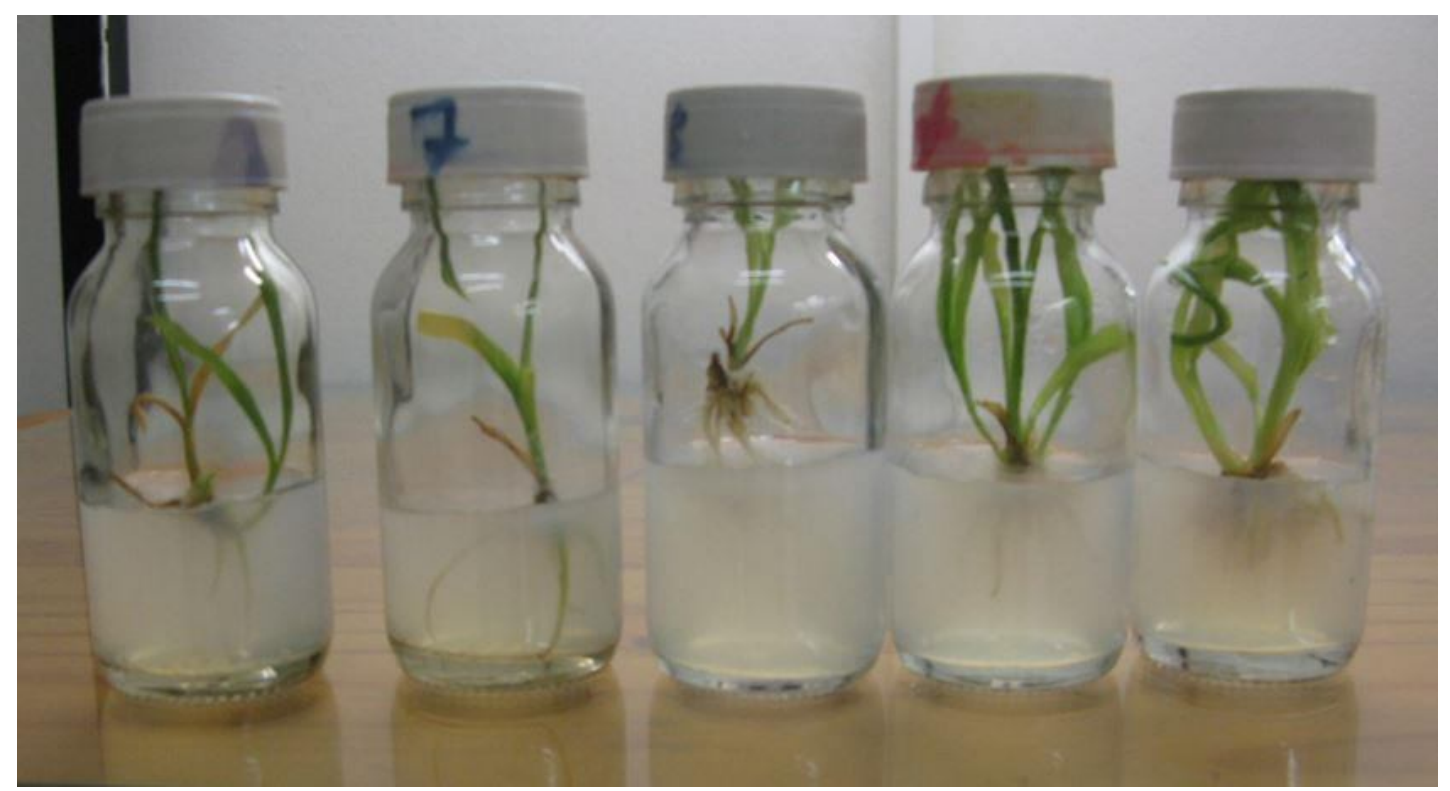

Figure 10. In vitro rooting of wild ginger plantlet on different NAA concentrations (from left to right: $0.0,0.5$, $\left.1.0,1.5,2.0 \mathrm{mg} \mathrm{L}^{-1}\right)$.

on Zingiber officinale by Zuraida et al. (2016), where 0.5 and $1.0 \mathrm{mg} \mathrm{L}^{-1}$ BAP produced same number of microshoots. In the present study, BAP concentrations above $2.0 \mathrm{mg} \mathrm{L}^{-1}$ were not effective at all in stimulating shoot regeneration of wild ginger. The combination concentrations of BAP and NAA did not induce shoots on wild ginger in vitro. One of the possible explanations given for this may be consistent with its high cytokinin activity (Arab et al., 2014). The high concentration of BAP $(2.0 \mathrm{mg} / \mathrm{L}) \mathrm{might}$ have released ethylene which inhibited shoot induction in vitro (Ashraf et al., 2014). Similar results were observed in Cicer arietinum (Murthy et al., 1996), where addition of NAA alone or in combination with $\mathrm{BAP}$ to the MS medium failed to induce multiple shoot formation. On micro-propagation of jatropha, combinations of BAP and NAA promoted the lowest amount of elongation, with the elongation ranging from 1.01 to $1.99 \mathrm{~cm}$ (Kumar and Reddy, 2010). However, BAP combined with Indole-3-butyric acid (IBA) was effective for regeneration of Alstroemeria ligtu (Nasri et al., 2013).

Explants on MS basal medium without any growth regulators regenerated shoots significantly higher than explants inoculated on MS media augmented with high concentration of BAP $\left(2.0 \mathrm{mg} \mathrm{L} \mathrm{L}^{-1}\right)$ and both the combination of BAP and NAA. Cytokinin and auxin concentrations in the medium were probably too high and thus inhibited shoot formation. Similar results were reported by Mithila et al. (2003) in African violet. Regeneration occurred also on growth regulator-free media on nodal explants of lilies (Bacchetta et al., 2003).

The half strength MS medium, with and without plant growth regulators, was effective in inducing wild ginger roots in vitro. The half strength MS medium without NAA and the one supplemented with $2.0 \mathrm{mg} \mathrm{L}^{-1} \mathrm{NAA}$ recorded $100 \%$ rooting in vitro, however, they were not significantly $(P>0.05)$ higher than the other NAA concentrations. These results concur with those reported by Kher and Nataraj (2017) where in the in vitro rooting of Combretum ovalifolium, $100 \%$ rooting was observed in MS medium augmented with auxins as well as on auxin free halfstrength MS medium. Formation of roots on auxin-free medium is a possible indication of the presence of endogenous auxin (Kher and Nataraj, 2017). However, contrary to the present study, in the in vitro propagation of Alstroemeria ligtu, roots were not formed without NAA in the medium (Nasri et al., 2013).

There was no noticeable difference among different concentrations of NAA in response to root number and root length on Kalanchoe blosseldiana (Kaviani et al., 2014). A similar trend was observed in the current investigation. Neither the number of roots per shoot nor the root length in all the NAA concentrations were significantly higher and longer than those in the half strength MS medium without any plant growth regulator. Auxin type and concentration had no significant effect on number of root per shoot and root length of Combretum ovalifolium (Kher and Nataraj, 2017). However, the number of roots increased with concentration of NAA, while the root length decreased with increase in NAA concentration in the in vitro rooting of ginger (Hiremath, 2006).

\section{CONCLUSION}

Wild ginger is amenable to micro-propagation. The in 
vitro shoot regeneration of the wild ginger is dependent on both the type of explant used, and the concentration of cytokinins, BAP in particular. The most effective explant of wild ginger to use for shoot regeneration via direct organogenesis is the corm explant. To induce shoot formation, the MS basal medium can be augmented with BAP at concentration levels of up to $1.0 \mathrm{mg} \mathrm{L}^{-1}$. Any BAP concentrations at or above $2.0 \mathrm{mg} \mathrm{L}^{-1}$ might have detrimental effect on direct shoot regeneration in vitro. The in vitro rooting of wild ginger can be achieved in half strength MS medium alone, or be supplemented with NAA at concentration of up to $2.0 \mathrm{mg} \mathrm{L}^{-1}$.

It is strongly recommended that surface sterilisation protocol be first developed for the micro-propagation of the wild ginger, especially if underground parts are to be used as explants, particularly if they are being introduced to in vitro propagation for the first time. It is also recommended that the synergistic effect of BAP and NAA on micro-propagation of wild ginger be further investigated, perhaps at concentrations lower than those used in the current study. Other plant growth regulators should be tried out in the in vitro propagation of wild ginger as well.

\section{ACKNOWLEDGEMENTS}

We would like to pass our sincere gratitude to the University of Eswatini for financial support to carry out this study. We also thank the Directors of Pasture Valley Farm for allowing us to use their plant tissue culture facility.

\section{REFERENCES}

Abdi G, Khosh-Khuni M, 2007. Shoot regeneration via direct organogenesis from leaf segments of valerian (Valerina officinalis L.). Int J Agric Res, 2(10): 877-882.

Ahmed AS, McGaw LJ, Moodley N, Naidoo V, Eloff JN, 2014. Cytotoxic, antimicrobial, antioxidant, antilipoxygenase activities and phenolic composition of Ozoroa and Searsia species (Anacardiaceae) used in South African traditional medicine for treating diarrhoea. South Afr J Bot, 95: 9-18.

Arab MM, Yadollahi A, Shojaeiyan A, Shokri S, Ghojah SM, 2014. Effects of nutrient media, different cytokinin types and their concentrations on in vitro multiplication of $\mathrm{G} \times \mathrm{N} 15$ (hybrid of almond $\times$ peach) vegetative rootstock. J Genet Eng Biotechnol, 12: 81-87.

Ashraf MF, Aziz MA, Kemat N, Ismail I, 2014. Effect of cytokinin types, concentrations and their interactions on in vitro shoot regeneration of Chlorophytum borivilianum Sant. \& Fernandez. Electron. J Biotechnol, 17: 275-279.

Bacchetta L, Remotti PC, Bernardini C, Saccardo F, Biotecnologie UTS, Genetica S, Vegetale G, Casaccia E, 2003. Adventitious shoot regeneration from leaf explants and stem nodes of Lilium. Plant Cell Tissue Organ Cult, 74: 37-44.

Briskin DP, 2000. Medicinal plants and phytomedicines: linking plant biochemistry and physiology to human health. Plant Cell Tissue Organ Cult, 96: 273-278.

Cavusoglu A, Sulusoglu M, Erkal S, 2013. Plant regeneration and corm formation of saffron (Crocus sativus L.) in vitro. Res J Biotechnol, 8: 128-133.

Dharishini MP, Krishna M, Balasubramanian K, 2015. Effects of plant growth regulators and activated charcoal on regeneration and plantlet development in Neer Brahmi (Bacopa monnieri). J Acad Ind Res, 4: 69-74.

Fouche G, van Rooyen S, Faleschini T, 2013. Siphonochilus aethiopicus, a traditional remedy for the treatment of allergic asthma. Int J Genuin Tradit Med, 3: 1-6.

Hartmann HT, Kester DE, Davies FT, Geneve RL, 2002. Plant propagation principles and practices. 7th Ed. Prentice Hall, Upper Saddle River, New Jersey. pp. 574.

Hartzell JF, 2011. Response of the endangered medicinal plant Siphonochilus aethiopicus (Schweif.) B. L. Burt. to agronomic practices. Unpublished thesis in fulfillment of the academic requirements for the degree of Master of Science in Plant Pathology, University of KwaZulu-Natal, Pietermaritzburg, KwaZulu Natal, South Africa.

Hiremath RC, 2006. Micropropagation of ginger (Zingiber officinale Rosc.). Unpublished thesis in partial fulfillment of the requirements for the degree of Master of Science (Agriculture) in Horticulture, University of Agricultural Sciences, Dharwad, India.

Kaviani B, Hashemabadi D, Kordi M, 2014. The effect of different concentration of plant growth regulators on micropropagation of Kalanchoe blosseldiana cv. White. J. Ornam. Plants, 4: 101-106.

Kher MM, Nataraj M, 2017. Micropropagation of Combretum ovalifolium Roxb.: a medicinally important plant. Rend. Fis. Acc. Lincei. DOI 10.1007/s12210-017-0625-z (Accessed on June 20, 2017).

Kumar N, Reddy MP, 2010. Plant regeneration through the direct induction of shoot buds from petiole explants of Jatropha curcas: a biofuel plant. Ann Appl Biol, 156: 367-375.

Kunene EN, Masarirambi MT, 2018. Role of biotechnology in the conservation of rare, threatened and endangered medicinal plant species in the Kingdom of Eswatini (Swaziland). Adv Med Plant Res, 6(3): 26-32.

Light ME, 2002. An investigation of the medicinal properties of Siphonochilus aethiopicus. Unpublished thesis in fulfilment of the requirements for the degree of Master of Science, University of Natal, Pietermaritzburg, South Africa.

Malik CP, Garg P, Singh Y, Grover S, 2012. Medicinal uses, chemical constituents and micro propagation of three potential medicinal plants. Int J Life Sci Pharma Res, 2: 57-76.

Manzini TZ, 2005. Production of wild ginger (Siphonochilus aethiopicus) under protection and indigenous knowledge of the plant from traditional healers. Unpublished thesis submitted in partial fulfilment of the requirements of the degree M. Inst. Agrar: Plant Production (Horticulture), University of Pretoria, Pretoria, South Africa.

Mithila J, Hall JC, Victor JMR, Saxena PK, 2003. Thidiazuron induces shoot organogenesis at low concentrations and somatic embryogenesis at high concentrations on leaf and petiole explants of African violet (Saintpaulia ionantha Wendl.). Plant Cell Rep, 21: 408414.

Mokhtari A, Zarei M, Samsamzadeh B, Moradi K, 2016. Interactive effects of plant growth regulators and explants on direct shoot regeneration of Viola odorata. J Biotechnol Comput Biol Bionanotechnol, 97: 33-39.

Murashige T, Skoog F, 1962. A revised medium for rapid growth and bioassays with tobacco tissue cultures. Physiol Plant, 15: 473-497.

Murthy BNS, Victo J, Singh RI, Fletcher RA, Saxena PK, 1996. In vitro regeneration of chickpea (Cicer arietinum L.): Stimulation of direct organogenesis and somatic embryogenesis by thidiazuron. Plant Growth Regul, 19: 233-234.

Nasri F, Mortazavi SN, Ghaderi N, Javadi T, 2013. Propagation of in vitro of Alstroemeria ligtu hybrid through direct organogenesis from leaf base. J Hort Res, 21: 23-30.

Seran $\mathrm{TH}, 2014$. In vitro propagation of ginger (Zingiber officinale Rosc.) through direct organogenesis: a review. Pak J Biol Sci, 1-10.

Sharma S, Shahzad A, Jan N, Sahai A, 2009. In vitro studies on shoot regeneration through various explants and alginate-encapsulated nodal segments of Spilanthes mauritiana DC., an endangered medicinal herb. Int J Plant Dev Biol, 3: 56-61.

Swaziland National Trust Commission, 2016. Swaziland's flora red list. http://www.sntc.org.sz/biodiversity/florardb.asp (Accessed on April 09, 2018). 
Tasheva K, Kusturkova G, 2013. Role of biotechnology for protection of endangered medicinal plants. In World's Largest Science, Technology and Medicine, Bocchiaro $\mathrm{P}$ and Zamperini $\mathrm{A}$ (Eds.), INTECH, pp. 235-285.

Xego S, Kambizi L, Nchu F, 2016. Threatened medicinal plants of South Africa: Case of the family hyacinthaeae. Afr $\mathrm{J}$ Trad Complement Altern Med, 13: 169-180.

Zuraida AR, Mohd SMA, Erny SMN, Ayu NO, Che RCZ, Pavallekoodi G, Sreeramanan S, 2016. Micropropagation of ginger (Zingiber officinale var. Rubrun) using buds from microshoots. Pak J Bot, 48: $1153-1158$
Citation: Kunene EN, Oseni TO, Wahome PK, Masarirambi MT, McCubbin MJ, Dlamini PS, Sihlongonyane SA, Zwane MG, 2018. Effects of plant growth regulators and explant type on the in vitro micro-propagation of wild ginger (Siphonochilus aethiopicus (Schweif.) B.L. Burt.). Adv Med Plant Res, 6(4): 54-63. 